\title{
A mulher Tenetehára contemporânea: identidade étnica, gênero e movimentos sociais
}

\author{
The contemporary Tenetehára woman: ethnic identity,
} gender and social movements

Cintia Maria Santana da Silva ${ }^{1}$

Marci Fileti Martins ${ }^{2}$

DOI: https://doi.org/10.26512/rbla.v11i1.26442

Recebido em março/2019 e aceito em abril/2019.

\begin{abstract}
Resumo
O artigo analisa a construção da identidade da mulher Tenetehára contemporânea que, atualmente, projeta-se nacional e internacionalmente a partir de seu protagonismo nos movimentos sociais. A análise proposta, baseada nos pressupostos teóricos da Análise do Discurso, mostra que o discurso recente de valorização da identidade indígena/da mulher indígena, que tem nos movimentos sociais seu destaque máximo, funcionaria potencializando o protagonismo que a mulher Tenetehára já tem dentro de seu próprio grupo. De fato, são as relações de força no interior do universo sociocultural Tenetehára organizadoras das relações de gêneros (posições da mulher/homem), os elementos determinantes para a constituição da identidade, da posição discursiva, dessa mulher. As relações de gênero no contexto sócio-histórico-ideológico Tenetehára, que se constituem por uma "flexibilidade" entre as posições da mulher e do homem, permitiria a mulher Tenetehára ocupar posições tradicionalmente masculinas. Os deslocamentos entre essas posições são tolerados e até mesmo desejados, pois vão funcionar garantindo a força da coletividade Tenetehára.
\end{abstract}

Palavras-chave: Discurso. Mulher Tenetehára contemporânea. Identidade étnica. Gênero. Movimentos sociais.

\section{Abstract}

The article analyzes the construction of contemporary Tenetehára women's identity. These women project themselves, nationally and internationally, through their roles in social movements. The proposed analysis, based on theoretical assumptions of Discourse Analysis, shows that the current discourse of indigenous women empowerment, which is mostly emphasized in social movements, works by reinforcing the role the tenetehára women already have within their own group. In fact, balance of power within the Tenetehára socio-cultural universe establishes gender relations (roles of women/men), the defining ingredients to

${ }^{1}$ Também conhecida como Cintia Guajajara, é mestra pelo Mestrado Profissional em Linguística e Línguas Indígenas - PROFLLIND, do Museu Nacional-UFRJ. É Vicecoordenadora da Articulação das Mulheres Indígenas do Maranhão (AMIMA), Conselheira da União das Mulheres Indígenas da Amazônia (UMIAB) e Secretaria Executiva da Coordinadora de las Organizaciones Indígenas de la Cuenca Amazónica (COICA). E-mail: cintiaguajajara@hotmail.com.

${ }^{2}$ Professora do Mestrado Profissional em Linguística e Línguas Indígenas - PROFLLIND, do Departamento de Antropologia - Museu Nacional-UFRJ. E-mail: marcifm@gmail.com. 
these women identity constitution. Gender relations in the Tenetehára universe seem to be constituted by a "flexibility" between the roles of women and the men, which gives women the possibility to occupying "male" positions. This displacement of roles is tolerated, and even desired, by the community, given that they strength the Tenetehára people as a group.

Keywords: Discourse. Contemporary Tenetehára woman. Ethnic identity. Genre. Social movements.

\section{Introdução}

AmulherTenetehára ${ }^{3}$, na atualidade, projeta-se nacional e internacionalmente a partir de seu protagonismo nos movimentos sociais, fato que se coaduna com a proposição de uma "emergência da identidade étnica feminina no movimento indígena na América Latina, como novos atores da sociedade civil." (Aguilar 2016:2). Se por um lado refletir sobre a identidade dessa mulher implica a compreensão da sua relação com os movimentos sociais, por outro envolve dimensioná-la partir de sua identidade étnica e de gênero. Como a análise que propomos aponta, são as relações de força no interior do universo sóciocultural Tenetehára, organizadoras das relações de gêneros, os elementos determinantes para a constituição da identidade da mulher Tenetehára contemporânea.

Tomando o discurso como observatório, a identidade dessa mulher é entendida como uma posição de sujeito em um discurso. De tal modo, gênero, identidade, assim como identidade étnica, conceitos já amplamente tratados na Antropologia e na Sociologia, serão aqui discutidos pela visada da Análise do Discurso ${ }^{4}$, da qual mobilizaremos alguns conceitos como os de formação discursiva, formação ideológica, interdiscurso (memória discursiva), assim como o de sujeito constuído por uma alteridade marcadamente heterogênea.

Os discursos de mulheres e homens Tenetehára materializados tanto pela língua tenetehára ${ }^{5}$ quanto pela língua portuguesa $^{6}$, ganham especificidade em depoimentos que abordam temas como o papel da mulher e do homem, políticas públicas (educação/saúde), luta pelo território, movimento indígena,

\footnotetext{
${ }^{3}$ Tenetehára ou Tenetehar é também a autodenominação do povo, que é conhecido conhecido como Guajajara no Maranhão e Tembé no Pará. Mesmo habitando algumas áreas no estado do Pará (aldeias Tenetehára-Tembé), é no Estado Maranhão, na região do Pindaré, aonde vivem a grande maioria do povo Tenetehára. De acordo com Silva (2014), a denominação Guajajára foi atribuída ao povo pelos não indígenas, sendo o resultado do empréstimo para o português da palavra waza'yzar, "donos dos enfeites".

${ }^{4}$ A teoria e o método da Análise do Discurso idealizada por Michel Pêcheux ([1975] 1988, [1983], 2007) foi, inicialmente, desenvolvida no Brasil por Eni Orlandi (1987, 1988, 1999).

${ }^{5}$ A língua Tenetehára foi classificada por Rodrigues (1986) como pretencente ao Ramo VI da família Tupi-Guarani (tronco Tupi).

${ }^{6}$ Devido a exigências editoriais não serão apresentados, nesse artigo, as versões dos depoimentos em língua tenetehára. Os materiais estão disponíveis na integra em Silva (2018).
} 
assim como em narrativas que versam sobre seus mitos e rituais. Os trabalhos de Zanonni (1999, 2002), Almeida (2012) e Ponte \& Aquino (2013), também devem ser citados, pois foram tomados como elementos para a compreensão da cultura e da sociedade Tenetehára e, por conseguinte, da questão em pauta nesse estudo.

\section{A identidade étnica Tenetehára como posição discursiva}

Na cabeça do índio tem duas pessoas, Maíra-yr e Mykurayr. $O$ índio não tem um plano certo. Ele não se define só. Dentro de sua cabeça tem duas pessoas Maira e Mykura-ir. Só aprende quando sofre muito. $\mathrm{O}$ eu do índio tá no pensamento de Morotó; Maíra, Mykura-ir, Xiapé.

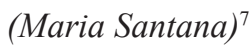

Ao discutir a relação entre sujeito e identidade, Hall (2004) destaca o que denomina "crise de identidade" na contemporaneidade, enfatizando com isso a necessidade de se repensar o conceito de identidade. O autor traz à baila considerações sobre o seu caráter hibrido, móvel, incompleto e propõe o uso das expressões "identificação" ou "processo identitário" para compreender de maneira mais significativa as representações que constituem os sujeitos: "Existe algo "imaginário" ou fantasiado sobre sua unidade. [...] Assim, ao invés de falar da identidade como uma coisa acabada, deveríamos falar de identificação, e vêla como um processo em andamento". (Hall 2004:38-39).

Comparando a noção de alteridade/identidade proposta por Hall com a da Análise do Discurso (AD), observamos afinidades, já que também para a $\mathrm{AD}$ o sujeito não é a fonte única do sentido, nem tampouco elemento onde se origina o discurso, é sim constituído, atravessado pelo(s) discurso(s) do(s) outro(s), discursos estes resultado de processos sócio-histórico-ideológicos:

Os Estudos Culturais assim como a Análise do Discurso encaram o sujeito numa mesma perspectiva, tratando-o não na esfera do individual, como um ser empírico, mas como um ser social, um "ser do discurso", constitutivamente disperso, fragmentado, múltiplo, assim como suas identidades. Não há identidade sem sujeito e também não existe sujeito sem discurso (HALL, 2001; ORLANDI, 2003). Estamos falando, também, de um sujeito polifônico, que se constrói na e pela linguagem, e, portanto, de um processo identitário que se constitui num jogo polifônico, no qual múltiplas vozes e dizeres interpelam, sustentam e/ou fraturam as identidades. (Meireles 2012:1)

Trata-se, então, de indagar sobre a identidade/alteridade da mulher

${ }^{7}$ Almeida (2012: 37). Maria Santana é uma importante liderança Tenetehára 
Tenetehára contemporânea (MTC) como uma posição de sujeito, sujeito este constitutivamente "fragmentado e polifônico interpelado por uma pluralidade de centros de poder, por diferentes formações discursivas ${ }^{8}$, diferentes vozes." (Meireles 2012:1). Nesse conjunto de representações subjetivas, em que a MTC se define a partir de sua posição em uma formação discursiva (FD) também constitutivamente heterogênea, destacamos o que se convencionou denominar, na Antropologia e na Sociologia, "identidade étnica".

Das proposições sobre o conceito de identidade étnica, apresentamos a do antropólogo norueguês Fredrik Barth ([1969] 2000), citado por Veras \& De Brito (2012). Os autores afirmam que, da perspectiva de Barth, não se pode definir etnicamente um grupo partindo do pressuposto biológico, cultural ou mesmo linguístico, mas pela forma como se identificam ou são identificados por outros:

Barth não está preocupado com a estrutura da sociedade, mas com a análise da interação e seus contatos. Um grupo surge quando cria categorias para se identificar e identificar outros, instituindo assim as fronteiras étnicas do nós e do eles. A construção dessa fronteira e sua manutenção são a base de sua pesquisa. (Veras \& De Brito (2012:111).

Do que se refere à identidade étnica indígena, notadamente, da mulher indígena, observa-se que no contexto contemporâneo, diferentemente de um passado nada distante, constrói-se, por certo segmento da sociedade não indígena, um movimento para a valorização e promoção da identidade indígena. Assistimos à emergência de movimentos sociais, assim como de políticas públicas, que buscam dar visibilidade e garantias de direitos às populações indígenas. No entanto, essas relações interétnicas não se estabelecem somente a partir da conjuntura contemporânea. Entra em jogo aí, a história da colonização da América pelos europeus. É sabido que a colonização como um processo de exploração, afetou profundamente os povos indígenas: foram chacinados, e os que sobreviveram foram espoliados de suas terras, de suas riquezas e de suas culturas.

O povo Tenetehára foi fortemente atingido pelo sistema colonialista. Os invasores não indígenas os encontram no início do século XVII e, em estudos dos anos 40, Wagley e Galvão (1961) chegaram a afirmar que "os Tenetehára, após intenso contato com a sociedade brasileira, não resistiriam ao "processo

\footnotetext{
8 "aquilo que, numa formação ideológica dada, [...] determina o que pode e deve ser dito (articulado sob a forma de uma arenga, de um sermão, de um panfleto, de uma exposição, de um programa, etc.)" (Pêcheux, [1975] 1988, p. 160). “[...] o ponto essencial aqui é que não se trata apenas da natureza das palavras empregadas, mas também (e sobretudo) de construções nas quais essas palavras se combinam [...] as palavras "mudam de sentido" ao passar de uma formação discursiva a outra." (Haroche, C. Pêcheux, M. Henry, P. [1971] 2008).
} 
de aculturação" e que não demoraria muito para que esse grupo desaparecesse enquanto um "povo tribal", tornando-se "caboclos"." (Ponte \& Aquino 2012:2). Não foi o que aconteceu:

Em estudos posteriores (cf. CEDI, 1985), verificou-se que apesar dos contatos favorecidos pelo Serviço de Proteção Indígena (SPI) entre os Tenetehára e Tembé, com habitantes próximos das aldeias, além da participação de boa parte dos homens como trabalhadores intermediários na "frente de atração" entre os Ka'apor, na década de 1950, e entre os Assuriní do Xingu, na década de 1970, os Tenetehára-Tembé do Gurupi continuavam vivendo, de certa forma, conforme os padrões encontrados nos estudos de Wagley e Galvão na década de 1940. "(Ponte \& Aquino 2012:2).

O exemplo Tenetehára expõe a complexidade envolvendo as relações de contato, e se entendidas como relações discursivas, apontam para a emergência de posições de sujeito em FDs: o sujeito indígena que enuncia de sua posição na FD indígena (FDInd), enquanto o sujeito não indigena o faz da sua posição na FD não indígena (FDNInd). Essas FDs se constituem pela interdiscursividade" ou seja, por um "conjunto de formulações feitas e já esquecidas [...] que retorna sob a forma do pré-construído, de um o já-dito denominado memória discursiva" (Orlandi, 1999:33-34). Esse “já-dito" que retorna, é atualizado ou apagado de acordo com as condições históricas-ideológicas ${ }^{10}$ que regulam a FDInd e a FDNInd, o que equivale dizer que as fronteiras entre a essas FD deslocam-se conforme os embates decorrentes das relações de força entre as formações ideológicas (FI) ${ }^{11}$ que as compõem.

O sujeito Tenetehára, desse modo, busca construir sua posição por meio do estabelececimento dos limites entre FDInd Tenetehára (FDIndT) e FDNInd. Nesse processo, constrói estratégias próprias para lidar com a sociedade envolvente, sendo que suas formas de negociação podem minimizar ou

9 "O interdiscurso é todo conjunto de formulações feitas e já esquecidas que determinam o que dizemos [...] é preciso que o que foi dito por um sujeito especifico, em um momento particular se apague na memória para que, passando para o "anonimato", possa fazer sentido [...]" (Orlandi, 1999:34).

${ }^{10}$ Da perspectiva da $\mathrm{AD}$, a ideologia também é pensada como tendo "materialidade" (Marx \& Engels, 1932). Contudo, não está restrita à classe dominante: deve ser entendida como elemento que determina o sentido e o sujeito: "O fato mesmo da interpretação, ou melhor, o fato de que não há sentido sem interpretação atesta a presença da ideologia. [...] Nesse movimento da interpretação o sentido aparece-nos como evidência. Como se ele estivesse sempre lá. Interpreta-se e ao mesmo tempo nega-se a interpretação, colocando-a no grau zero. Naturaliza-se o que é produzido na relação do histórico e do simbólico. (Orlandi 1999:45-46)"

11 “conjunto complexo de atitudes e representações que não são nem individuais, nem universais, mas se relacionam mais ou menos diretamente a posições de classes em conflito umas com as outras". (Pêcheux; Fuchs, 1993:166) 
maximizar conflitos. De fato, Almeida (2012) em sua dissertação de mestrado "SER COMO O BRANCO, NÃO É SER O BRANCO": dinâmicas de controle e transgressão nas relações interétnicas- analisa como se estabelece, por parte do povo Tenetehára, a execução das políticas indigenistas de saúde e de educação. O autor apresenta por um lado, as dinâmicas de controle do Estado sobre os Tenetehára e, por outro, as estratégias de transgressão a esse controle, acionadas por eles. Nesse contexto, examina uma das três ocupações do prédio da FUNASA, que ocorreu no mês de outubro de 2003. Nessa ocupação, cerca de 400 indígenas acamparam na sede da Fundação Nacional de Saúde, em São Luís, no Maranhão, o que exigiu a presença do Ministério Público Federal e uma audiência marcada para o dia 03 de novembro de 2003.

Descataca-se aí, o fato de uma das lideranças indígenas, que se negava a reforçar o movimento Tenetehára e pretendia desarticulá-lo, ter mudado seu posicionamento e ao fazê-lo trouxe, para São Luís, 80 pessoas, garantido com isso um maior número de adesão para as propostas dos Tenetehára. O episódio, segundo o referido autor, traz um desdobramento interessante, pois mostra que "a força política Tentehar extrapola as divergências internas e acaba por definir o rumo dos acontecimentos" (Almeida 2012:56).

A narrativa do mito de origem Maira'yr e Mykura 'yr ("Filho de Maíra e filho de Mucura") ${ }^{12}$ feita por Cipriano Guajajara, apresentada na mesma dissertação, pode ser entendida, também, como uma dessas formas de negociação. Almeida (2012:31) afirma que Cipriano ao se posicionar como os "próprios" civilizados e senhores de todas as terras", dá pistas de como se constrói a alteridade Tenetehára. Apresentamos a seguir um extrato do depoimento de Cipriano Guajajara, citado em Almeida (2012:30-31):

"Maíra e seus filhos saem à procura de um lugar para morar. [...] Chegam a uma ilha e decidem 'é aqui vamos morar'. Constroem uma casa grande, caiada de branco, e convidam os índios a virem morar com eles fazendo um grande povoado. Lá fabricam de um tudo: espingarda, roupa, sabão, facão, querosene, fósforo, [...] e fazem uso do dinheiro. Isto é, eles são os próprios civilizados. Maíra-yr vira São Pedro, Mykura-yr fica sendo Joãozinho, e o velho Maíra vira o Governo. [...] O lugar que isso acontece é o Rio de Janeiro."

Jogando com a polissemia ${ }^{13}$ constitutiva dos processos simbólicos, Cipriano Guajajara assume a posição do "civilizado" e do "fabricante de tudo" construindo pra si um espaço que lhe permite por um lado agenciar a memória

\footnotetext{
${ }^{12}$ No anexo deste material, apresentamos uma outra versão do referido mito.

${ }^{13}$ De acordo com Orlandi (1999:36-37) a polissemia e a paráfrase são processos que representam a tensão constante estabelecida pela relação homem/mundo atravessada pela linguagem.
} 
da colonização que lhe inferioriza, e por outro acessar as "coisas" dos não indígenas - já que eles, os Tenetehára, também sabem fabricá-las.

Configura-se, assim, o modo como o sujeito Tenetehára negocia com as forças do contato demarcando os limites entre as FD. Agenciando os conflitos (internos/externos) que regulam as relações de força entre a FDIndT e a FDNInd, Cipriano Guajajara e a liderança do movimento indígena buscam, cada um a seu modo, construir suas posições na FDIndT.

Diante da complexidade envolvendo o trabalho de delineamento da FDIndT, e não sendo o objetivo principal deste trabalho a sua rigorosa caraterização, diremos que dos elementos que a constituem, a sua relação interdiscursiva com a FDNInd é fundamental. E se levarmos em consideração que a interdiscursividade se produz na relação: "no sentido de que esta relação não se dá a partir dos discursos já particularizados. [...] ou seja, são as relações entre discursos que particularizam cada discurso" (Guimarães 1993 apud Orlandi [1996], 2007:68), podemos afirmar que a constituição da FDIndT se dá, sobretudo, na tensão com as relações de força das FI que sustentam a FDNInd.

\section{A mulher Tenetehára tradicional e (não) tradicional: as fronteiras entre a FDInd Tenetehára e a FDNInd}

A identidade da MTC entendida como uma posição na FDIndT emerge, portanto, da sua relação com a outra identidade, com a outra posição na FDNInd. $\mathrm{O}$ discurso dessa mulher, determinado por essas relações, ganha materialidade no depoimento de Maria Judite da Silva Ballerio Guajajara ${ }^{14}$ :

"Bom, é...eu tenho uma visão mais tradicional, com relação a esse aspecto, eu sou um pouco digamos...é eu sou um pouco conservadora com relação a esse aspecto da mulher indígena, por que eu acredito que apesar de poder sair da comunidade e encontrar todos os desafios necessários para poder concluir uma graduação, ou conseguir concluir um mestrado ou doutorado, vc deve manter, necessariamente, manter suas raiz tradicionais então eu sou conservadora nesse sentido. Porem eu acredito que sim... há uma necessidade e além da necessidade há uma importância em permitir, em apoiar que as mulheres indígenas que sejam jovens ou mais velhas, estejam em busca ou continuamente em busca desses conhecimentos, ou mesmo de trabalhos, ou mesmo

\footnotetext{
${ }^{14}$ Maria Judite da Silva Ballerio Guajajara, tem 22 anos. É graduada em Direito pela Universidade Federal do Maranhão - UFMA e reside na Aldeia Lagoa Quieta, do Território Araribóia, Município de Amarante, no Estado do Maranhão. Falante bilíngue do tenetehára e do português, juntamente com outras lideranças indígenas femininas participou, como representante da Rede da Juventude Indígena - REJUIND, de evento promovido, em 2013, pela ONU Mulher, nos Estados Unidos e na Guatemala.
} 
desenvolver uma vida além comunidade, porém mantendo a suas formas tradicionais de pensamentos as formas tradicionais de culturas. Por que assim, digamos que a possibilidade de você estar em uma universidade e ao mesmo tempo você manter suas raizes culturais e isso manter seus pensamentos ideológicos, e não você sair para estudar e adquirir um pensamento ideológico que vai contra as suas raízes culturais, então eu acredito que, então, sou conservadora nesse sentido. Eu acredito que há necessidade de a mulher indigena sair de sua comunidades encontrar outras oportunidades, porem sendo guiada por suas raizes ideológicas culturais."

Do discurso de Maria Judite, emergem, engendradas por diferentes sentidos, duas posições: da "mulher tradicional" que deve manter "a suas formas tradicionais de pensamentos as formas tradicionais de culturas", e uma outra, da "mulher não tradicional" que deve "desenvolver uma vida além comunidade". Outro discurso em foco, o de Maria do Amparo da Silva ${ }^{15}$, se comparado ao de Maria Judite, mostra que a negociação entre as diferentes vozes dessas mulheres pode resultar numa atualização diferenciada das memórias que sustentam cada uma delas:

"Eu me considero uma mulher tradicional, pois eu vivo mais e dentro da comunidade, e pra poder sair da comunidade é aquela dificuldade, eu boto toda dificuldade e pra mim não demostrar aquilo, eu tenho medo de ser uma coisa lá fora eu tem medo de perder a minha tradição dentro da comunidade, porque dentro da comunidade eu vejo tudo: eu vejo as brincadeiras, eu vejo as festas, eu vejo como meus parentes veve na aldeia, eu vejo como as crianças quando nascem começam brincar, que brincadeiras eles vão brincar, quais são as brincadeiras eles vão brincar, então eu tou vendo ali o dia a dia, nessa parte aí eu me considero e quando as vezes eu saio da comunidade vou pra fora aí, eu conheço outras coisas que não vejo na minha comunidade.

Como mulher tentehar, eu ocupo não só na escola, mas também eu mexo com roça né, planto mandioca, faço farinha, vou capinar plantar, colher [...] também vou pescar isso é o dia a dia da gente na comunidade, junto com a comunidade, junto com os caciques por que isso que eles praticam diariamente quando vamos pra roça rancar mandioca fazer farinha, então isso faz parte da cultura da gente, das coisas que agente faz dentro da comunidade." Bom quando chega as pessoas aqui, ele (cacique) sempre me pede como eu sou professora, ele quer que a gente recebe, quer a comunicação das pessoas que chega lá na comunidade, ele não quer que a gente fique lá longe, ele quer que a gente dá atenção."

\footnotetext{
${ }^{15}$ Maria do Amparo da Silva, 56 anos, reside na Aldeia Nova Viana, do Território Araribóia, município de Amarantes, Maranhão, onde atuou como professora. Falante bilíngue do tenetehára e do português, atualmente, é professora na Aldeia Juçaral, também do Território Araribóia.
} 
No discurso de Maria do Amparo, enquanto a voz da mulher não tradicional, a da professora, é quase silenciada, a outra, a da mulher tradicional, aparece constantemente no seu discurso, materializada pelas referências ao seu modo de vida (FDIndT):

"Como mulher tentehar, eu ocupo não só na escola, mas também eu mexo com roça né, planto mandioca, faço farinha, vou capinar plantar, colher [...] também vou pescar [...]

"[...] porque dentro da comunidade eu vejo tudo: eu vejo as brincadeiras, eu vejo as festas, eu vejo como meus parentes veve na aldeia, eu vejo como as crianças quando nascem começam brincar, que brincadeiras eles vão brincar, quais são as brincadeiras eles vão brincar, então eu tou vendo ali o dia a dia."

"[...] e pra poder sair da comunidade é aquela dificuldade, eu boto toda dificuldade [...] eu tenho medo de ser uma coisa lá fora eu tem medo de perder a minha tradição."

As duas mulheres Tenetehára: Maria Judite e Maria do Amparo, como sujeitos de sua FD, representam diferentes posições nesse embate pela particularização da FDIndT: para Maria Judite a fronteira entre a memória indígena (FDInT) e não indígena (FDNInd) delimita-se pela maior aceitação da voz do "outro", do não indígena. Já para Maria do Amparo, a "outra" voz deve ser mais controlada. Os limites da FDIndT, portanto, não são traçados de forma definitiva e as suas fronteiras deslocam-se em função das relações de força aí constituídas e do seu consequente agenciamento.

\section{A mulher Tenetehára e os movimentos sociais}

A identidade/posição MTC, que aqui se configura, constitui-se, portanto, pela particularização da da FDIndT em que pesa a delimitação diferciada das memórias (FDIndT/FDNInd) que são atualizadas. Sujeito dividido que é, a MTC se funda na tensão entre as vozes da mulher Tenetehára tradicional (MTT) e da mulher Tenetehára não tradicional (MTNT).

Se por um lado afirmamos que a cosmogonia Tenetehára ${ }^{16}$ (FDIndT) pode

\footnotetext{
${ }^{16}$ Zannoni (2012) ao analisar as relações de gênero na sociedade Tenetehára, enfocando especificamente o papel da mulher nos mitos fundamentais, afirma que se por um lado, a mulher é considerada a reprodutora, já que é aquela que dá à luz, ou aquela que empresta o invólucro ao marido, por outro também pode ser comparada à figura do "trickster. Este é o elemento que "corresponde a uma função simbólica reequilibradora das relações Homem-Natureza". (Zannoni 2002:89). Essas relações simbólicas criadas pelos mitos que dão sentido à cosmogonia Tenetehára trazem também elementos para compreendermos a práxis cotidiana, ou seja, aquilo que na sociedade/cultura Tenetehára configura-se como sendo da competência da mulher. De fato, as relações simbólicas estabelecidas pelo
} 
ser observatório produtivo para a compreensão da posição da MTT, por outro, os modernos discursos de valorização e promoção da identidade indígena(FDNInd), são espaços para o delineamento da posição da MTNT. Assim, da complexa rede de filiações ideológicas que FDNInd destacamos as duas memórias: uma da colonização e a outra aqui denominada memória da contemporaneidade. Desta última, os movimentos sociais ${ }^{17}$ insurgem como espaço de circulação da mulher Tenetehára e podem ser considerados os pontencializadores máximos dos movimentos de valorização da diversidade étnica.

A participação da mulher indígena nos movimentos sociais, notadamente no movimento indígena, está ligado aos objetivos fundamentais desse último: a luta pelo território. Demandas relacionadas a outros direitos adquiridos, como por exemplo, direito à educação e à saúde, também abrem espaço para mulheres. Como já mencionado, a relação do povo Tenetehára com essas as políticas públicas, é uma relação construída pelo conflito e, por conseguinte, pela tentativa de resolução dos mesmos. O episódio da ocupação do prédio da FUNASA, em outubro de 2003, em São Luís, que é exemplar no sentido de evidenciar o modo como os Tenetehára agenciam os conflitos e alianças tanto internamente, quanto com as forças do contato, também é elemento para a compreensão do papel de uma liderança Tenetehára. No caso em questão, a liderança que, inicialmente, pretendia desarticular o movimento termina por fortalecê-lo, e resurge como "herói":

A presença numérica já seria um fator de extrema pressão para com os órgãos com os quais negociavam, no entanto, o protagonismo devia ser exercido, também, no discurso, na palavra e na participação. $\mathrm{O}$ exemplo daquele que se nega a participar, a princípio, para depois despontar como um dos "heróis" da negociação pode ser lido como uma manobra política eficiente. Longe de representar a individualidade de seu próprio ponto de vista, a liderança indígena é reconhecida por sua capacidade de falar por muitos, em nome de muitos. (Almeida 2012:56-57)

Evidencia-se, assim, o poder de uma liderança Tenetehára por meio de uma de suas característica mais marcantes: "uma liderança indígena é reconhecida por sua capacidade de falar por muitos, em nome de muitos", assemelhando-

binômio humanidade versus natureza, orientariam as relações sócio-culturais Tenetehára direcionando os papéis sociais desempenhadas pelos homens e das mulheres. Essa memória mítica, assim, pode ser entendida como um dos elementos que constitui as condições de produção do discurso da mulher Tenetehára, de onde emerge sobretudo a voz da mulher Tenetehára tradicional (MTT). Essa discussão pode ser resgatada na integra em Silva (2018).

${ }^{17}$ De maneira ampla, os movimentos sociais podem ser conceituados "como respostas práticas e coerentes à distribuição desigual das privações sociais criadas pela mudança institucional.” (Alexander 1998 apud Aguilar 2013:5). 
se a líderes não indígenas que se projetam nos movimentos socias. Contudo, essa semelhança se esvanece ao se constatar que a posição de uma liderança Tenetehára está vinculada a uma outra que é a do "chefe de uma família extensa".

A "família extensa" definida por Wagley e Galvão (1955 apud Almeida 2012:129) como um conjunto de mulheres (as filhas e as filhas dos irmãos de indivíduo) "chefiadas" por um homem, é tambem considrada uma "unidade social", na qual estão contidos todos os elementos distintivos de uma comunidade Tentehára (Zannoni 1999 apud Almeida 2012:129). Almeida (2012) citando novamente Wagley e Galvão (1955), afirma que cabia os chefes de família articular todas as dimensões da vida social Tentehára:

Embora Zanonni (1997) afirme ser o conflito o fomentador das relações, entendo que é a sagacidade e a habilidade de cada chefe de família que propicia a construção de redes entre famílias extensas (ALMEIDA, 2009, p.64). O grande objetivo seria determinar o rumo das coisas e as alianças, assim como os conflitos são importantes para atingir esse fim. A construção do máximo de alianças possíveis, menos que a destruição dos adversários, que em outros contextos são potenciais aliados, tem sido a estratégia por excelência dos Tentehar. Por outro lado, as alianças não podem anular os poderes políticos de um chefe de família. Dessa maneira, cada vez que uma aliança se mostra desvantajosa é substituída ou rompida até que novos tratados sejam feitos. (Almeida 2012:130) (Grifo nosso)

O protagonismo dos homens Tenetehára no movimento indígena parece, portanto, ser fato esperado: de chefes de família passam à posição de liderança de suas comunidades tendo como função a resolução de conflitos. Sua posição na comunidade lhes dá visibilidade para assumirem posições de liderança também no movimento indígena. Já as mulheres, se entendidas como "membros desse conjunto chefiadas por um homem" que compõe a família extensa, tem sua posição na sociedade Tenetehára relacionada ao domínio doméstico e privado $^{18}$ e não ao do político e do público. Assim, questiona-se como se dá, na dinâmica das posições de gênero da sociedade Tenetehára, a passagem da sua posição de sujeito comandado para a outra, aquela do sujeito que comanda. Interessa compreender, portanto, as relações histórico-político-ideológicas que, organizando o universo Tenetehára, legitimam as mulheres a assumirem posições tradicionalmente masculinas, garantindo-lhes protagonismo dentro e fora de suas comunidades ${ }^{19}$.

\footnotetext{
${ }^{18}$ Sobre esse tema ver Zannoni (2002).

${ }^{19}$ Esse protagonismo, na atualidade, é representado exemplarmente pela figura de Sônia Bone Guajajara. Ela é Coordenadora Executiva da Articulação dos Povos Indígenas do Brasil (APIB), a instância máxima de aglutinação e referência nacional do movimento indígena no Brasil. Na eleição presidencial de 2018, no Brasil, foi candidata à vice-presidência
} 
Almeida (2012) pode novamente ser mencionado, quando assinala o modo como se dão as ações das famílias extensas no sentido de determinar a ocupação dos cargos vinculados aos órgãos de Estado:

Estas posições são ajustadas no seio da família e fazem parte das negociações no mercado de bens simbólicos. No exercício das políticas públicas da saúde e de escolarização o acesso a estes cargos passa pela anuência da liderança indígena, mais que isso, são controlados por ela. No entanto, não podem monopolizá-los ao ponto de inviabilizar a entrada de novos ocupantes, sob pena de perder poder de barganha e diminuir a influência sobre outras famílias. (Almeida 2012:141)

No mesmo estudo, observa-se que muitos dos cargos públicos da educação (Secretária de Educação - SEDUC) e da saúde (Fundação Nacional de Saúde FUNASA) são ocupados por mulheres, e que, se consideradas as afirmações de Almeida, essas posições seriam assumidas com a "anuência" da liderança de uma família extensa. A formação acadêmica: "a universidade, a graduação, o mestrado, o doutorado", como destaca Maria Judite da Silva Ballerio Guajajara, dessa perspectiva, também pode ser entendiada como uma posição negociada no seio das relações familiares, e é exemplar para mostrar como essas colocações podem abrir espaços para as mulheres atuarem nos movimentos sociais. De fato, a própria Maria Judite da Silva Ballerio Guajajara é representativa aqui, no sentido de mostrar que essa posição negociada no seio das relações familiares podem abrir espaços para as mulheres atuarem nos movimentos sociais. A própria Maria Judite, que é graduada em Direito pela Universidade Federal do Maranhão - UFMA, iniciou, com outros jovens indígenas, o Movimento dos Jovens Indígenas do Maranhão e, juntamente com outras lideranças indígenas femininas, participou como representante da Rede da Juventude Indígena REJUIND de evento promovido pela ONU Mulher, nos Estados Unidos e na Guatemala.

Dos efeitos da memória da colonização que compõe a interdiscursividade constitutiva daFDNInd, destaca-se o surgimento em 1910, do Serviço de Proteção aos Índios (SPI), órgão subordinado ao Ministério da Agricultura, que vigorou até 1967, quando foi substituído pela Fundação Nacional do Índio (FUNAI). Uma das estratégias do SPI, como órgão da chamada frente de expansão, era a "frente de atração", que se utilizava do chamados "índios mansos" como intermediários no contato entre o "branco" e índios "brabos". Essa ação visava, de acordo com Ponte \& Aquino (2013) facilitar a introdução da ação do SPI nas nos territórios tradicionalmente reconhecidos como pertencentes a esses grupos ou pelos espaços onde esses circulavam.

da república, ao lado de Guilherme Boulus (candidato à presidencia), pelo PSOL (Partido Socialismo e Liberdade). 
É sabido que o povo Tenetehára foi afetado por esse tipo de ação do SPI, já que boa parte dos homens Tenetehára foi recrutado como trabalhador intermediário nessa "frente de atração" entre os Ka'apor, na década de 1950, e entre os Assuriní do Xingu, na década de 1970. Uma consequência direta dessa política foi uma mudança na organização político-social do grupo, por meio da qual as mulheres passam a assumir funções, tradicionalmente, masculinas:

Conforme relatório do IPHAN (2011), o envolvimento dos TeneteháraTembé na frente de atração foi determinante na forma de organização política e social do grupo, sobretudo, porque com a saída dos homens, as mulheres assumiram a condução das aldeias, direcionando uma nova dinâmica e determinando o surgimento de importantes lideranças, principalmente de figuras femininas (Ponte \& Aquino 2013:2).

$\mathrm{O}$ discurso de outra mulher Tenetehára, Suluene Kuzàwy Tenetehára ${ }^{20}$, parece corroborar a historiografia oficial pela qual a posição de liderança assumida pelas mulheres se deve à ausência da presença masculina:

"Sou Suluene Kuzàwy Tenetehára [...] e quanto a liderança, o espaço que estou ocupando hoje, vem da raiz, eu vou falar um pouco da minha mãe, o depoimento da minha mãe, que nós somos de uma familia de mulheres que temos pouco homens na familia e pela necessidade, por nós ter poucos homens na família, as mulheres ter ocupado espaço junto com os homens, no trabalho, nas pescarias, nas roças, sempre trabalhar de igual pra igual com os homens, porque nossa familia tinha poucos homens, e os poucos homens que tinham lideram as outras mulheres. Nós temos muitas mães solteiras na nossa familia, e por nos ser família de poucos homens ocupamos os espaços muito cedo. Minha mãe se tornou liderança muito cedo, se tornou parteira aos 15 anos por necessidades. [...]"

A situação delineada no Território Araribóia pelo depoimento de Suluene Kuzàwy, vem ao encontro da realidade dos Tenetehára-Tembé do Gurupi ${ }^{21}$. Ponte \& Aquino (2013) destacam o surgimento de importantes lideranças femininas, das quais citam Verônica Tembé, que passou a assumir controle político depois que as frentes de atração recrutaram os homens para o trabalho junto aos "índios bravos".

\footnotetext{
${ }^{20}$ Suluene Kuzàwy Tenetehára tem 44 anos. Reside na Aldeia Lagoa Quieta, Território Araribóia, Município de Amarante, no estado do Maranhão. Falante bilíngue do tenetehára e do português, é graduada em Serviço Social e Coordenadora do Polo Base de Saúde Indígena do município de Amarantes.

${ }^{21}$ São chamados Témbe "o ramo ocidental dos Tenetehára que migrou do Pindaré (MA) até os rios Guamá, Capim e Alto Gurupi (PA). (Ponte \& Aquino 2013:3).
} 
Dessa perspectiva, as posições de protagonismo que as mulheres Tenetehára passam a ocupar dentro e fora da sua comunidade estão ligadas também às forças engendradas pelo contato. Dito de outra maneira, mesmo sendo essas posições determinadas pelas relações de parentesco, em que a família extensa é base reguladora, a variável "ausência de homens", por sua vez decorrente do contato, é um elemento a ser considerado no que diz respeito à atuação das mulheres no âmbito público e político. Assim, a trajetória e o protagonismo das mulheres Tenetehára no movimento indígena poderiam ser descritos da seguinte forma:

- com a insuficiência de homens no conjunto uma família extensa, as mulheres Tenetehára como "membros" dessa família seriam indicadas pelas lideranças para ocupar cargos públicos;

- com a consolidação das políticas públicas para a educação, tanto as servidoras públicas quanto outras mulheres, passam a adquirir formação no sistema educacional indígena e não indígena;

- dessas posições, passam a participar dos movimentos sociais, o que resulta na sua adesão e protagonismo no movimento indígena.

Evidencia-se aí o enredamento das relações estabelecidas pelo contato ao se constatar que as duas memórias, da colonização e da contemporaneidade, mesmo contraditórias, produzem o mesmo efeito de sentido: o protagonismo da mulher Tenetehára, dentro e fora de seu grupo é determinado pela FDNInd. Dessa perpectiva, a MTC, aquela aparece a frente dos movimentos sociais na atualidade, constitui-se como um sujeito muito mais determinado pela voz da MTNT (FDNInd). Entretanto, apesar da força engendrada por essa FDNInd "não há ritual sem falhas" (Pêcheux 1990:17).

\title{
A "flexibilidade" das posições de gênero e a memória da tradição
}

Eis a afirmação de Pêcheux:

\begin{abstract}
"E acrescentaremos que levar até as últimas conseqüências a interpelação ideológica como ritual supõe o reconhecimento de que não há ritual sem falha, desmaio ou rachadura: "uma palavra por outra" é uma definição (um pouco restritiva) da metáfora, mas é também o ponto em que um ritual chega a se quebrar no lapso ou no ato falho." (Pêcheux 1990:17).
\end{abstract}

Interessa-nos explorar, nas relações de força que sustentam as posições de sujeito das FDIndT e FDNInd, em que o sujeito não indígena - o responsável pela introdução das políticas públicas/movimentos sociais e pela cooptação dos homens Tenetehára - aparece como elemento determinante, o aparecimento de 
"pequenos lugares de esgarçamento dessa ideologia dominante"22. Do Território Araribóia, o discurso de Itamar Rodrigues de Sousa Guajajara ${ }^{23}$ oscilando entre a vida presente e passada de mulheres Tenetehára, nos dá pistas desses "pequenos lugares", nos quais a memória da FDNInd Tenetehára passa a ser atualizada, determinando "o que pode e deve ser dito":

"Bom eu sou Itamar, liderança de muitas lutas e quero falar um pouco das mulheres aqui hoje, como eram as mulheres do passado e do presente aqui hoje. Então, as mulheres guajajaras, elas sempre se dedicavam as coisas delas eram em casa, por exemplo: é torrar farinha, fiar algodão, fazer redes e essas coisas que elas faziam antes, eu não vou me aprofundar muito. Por essas coisas que eu vi a minha: meu pai tinha duas mulheres ele, convivia com umas e outras. Meu pai era pajé, vivia cantando nas aldeias, fazia curativas nas aldeias dos parentes fazia cura e era assim. Minha mãe fazia quase tudo, só não fazia derrubar roça, mas ela capinava, plantava, fazia farinha, caçava pescava de anzol e secava o poço para pegar peixe e ela cavava tatu e matava. Criou os filhos, criou os netos, e assim eu vi também várias outras indigenas que também lutaram. E ela ajudava ele nos cantos, faziam rituais dele também porque ele era pajé inclusive ela fazia tudo isso, eu me lembro muito bem o papel que ela fazia na comunidade. Criou os filhos, criou os netos, e assim eu vi também várias outras indigenas que também lutaram como eu vi, também, a comadre Maria, antes de ser servidora pública do governo, ela criou os filhos delas sozinha, ela fazia tudo isso que eu falei, ela criou os filhos sozinha pescando, trabalhando em roça sozinha, é que ela era, também como parteira pegava as criança das outras indigenas quando vinha ganhar menino, ela era convidada para fazer parto na comunidade, hoje ela sente muita falta porque ela era muito valorizada, iam atrás mesmo, iam atrás e levam ela e depois iam deixar, e ela se sentia muito, se sentia muito grata por isso e assim as outras indigena, também guajajara que tiveram essa luta, que antes elas só faziam esse tipo de trabalho de casa, de criar seus filhos, fazia as coisas mesmo de casa, de roça também como fazer farinha plantar colher, e algumas também fazia alguma coisa, artesanato, rede. E nessa aldeias indigenas Guajajara, não existia caciques (mulher), hoje já existe cacique: as

22 "É importante ressaltar que apesar da força engendrada pela colonização linguística, não há ritual sem falhas. Assim sendo, à revelia da colonização linguística imposta pela metrópole, pequenos lugares de esgarçamento nessa ideologia de dominação pela língua do colonizador vão sendo constituídos." (Mariani 2003:81)

${ }^{23}$ Tem 50 e poucos anos. Foi, por muitos anos, liderança da Aldeia Iporangatu, do Território Araribóia, no município de Bom Jesus das Selvas, estado do Maranhão. Falante bilíngue do Tenetehára e do português, atualmente, é vice coordenador da Comissão de Caciques do Território Araribóia - COCALITIA. 
indigenas já exerce essa função e assim vem modernizando essa luta: a mulher também vem acompanhando e ocupando o seu espaço de luta para a defesa de seu povo e seu direito e isso que vem acontecendo, e hoje as indigenas guajajaras, elas vem se destacando muito na luta de defesa de seus direitos, como tem a grande representante nossa como a Guajajara, temos as outras indigenas tem a Suluene, que ela ocupa hoje um cargo importante na saúde para seu povo. Temos as outras indigenas que também já anda em busca de conhecimento, aprender mais, fazer faculdade, como essa guerreira Cintia Guajajara, ela está se destacando bem no nosso povo, então as indígenas Guajajara estão se destacando muito bem em busca de melhoria para seu povo".

Do que interessa destacar, diremos que o discurso de Itamar Guajajara é marcado pela memória da tradição materializada em enunciados tais como: [...] Então, as mulheres Guajajaras, elas sempre se dedicavam as coisas delas eram de casa [...]", em que as expressões "sempre" e "coisas delas eram de casa" estabilizam esses sentidos conservadores. Ao mesmo tempo, pontos de contradição podem ser vislumbrados quando Itamar Guajajara afirma que [...] Minha mãe fazia quase tudo, só não fazia derrubar roça, mas ela capinava, plantava, fazia farinha, caçava pescava de anzol e secava o poço para pegar peixe e ela cavava tatu e matava [...]. De fato, mesmo as "mulheres do passado", como sua mãe, Pirawehy (Zilda Guajajara), faziam já muito mais que as "coisas delas", pois faziam "quase tudo". Sobressai-se nesse "quase tudo" até mesmo os afazeres relacionados à pajelança, tradicionalmente interditado às mulheres ${ }^{24}$ : "[...]E ela (mãe) ajudava ele nos cantos, faziam rituais dele também porque ele era pajé inclusive ela fazia tudo isso, eu me lembro muito bem o papel que ela fazia na comunidade".

As mulheres Tenetehára do Território Araribóia, assim, já assumiam posições tradicionalmente masculinas "mesmo tendo um marido" ou "antes mesmo de assumirem cargos públicos": "[...] a comadre Maria (Maria Santana), antes de ser servidora pública do governo [...] ela fazia tudo isso que eu falei [...]", o que põe em causa a força da FDNInd na determinação das dinâmica das posições de gênero na sociedade Tenetehára. Um olhar mais atento para os Tembé do Gurupi, mostra também que Verônica Tembé, uma das mais importantes lideranças Tenetehára-Tembé, não vivia "sozinha": foi "juntamente com seu marido", que ela "aproximou os Tembé dispersos ao longo do Gurupi, criando uma nova aldeia, a aldeia Tekohaw”. (Ponte e Aquino 2013:2-3).

\footnotetext{
${ }^{24}$ Aos homens é dada a autoridade para lidar com sobrenatural, enquanto à mulher é interditado assumir essa posição: "Maíra, o marido, lidava com o sobrenatural. Este se encontrava com os "encantados" e deles recebia os alimentos. A mulher, ao contrário, não sabia lidar com os sobrenaturais, aliás, nem podia; estava ligada ao trabalho, à práxis; práxis esta que a levava a ter uma "visão de mundo" diferente do companheiro." (Zannoni 2012:77)
} 
Outro discurso, o de Maria Santana ${ }^{25}$, é aqui mobilizado e materializa a voz de uma das principais figuras femininas do povo Tenetehára do sul do Maranhão. Como liderança, "antes de ser servidora pública do governo", atuou na luta pelo território, e pela reafirmação e preservação da cultura de seu povo:

Se reuniam, zaha tar brasilia pe, ma'e ar mehe ma'e xixak, ma'e rakykwer romo zaha tar a'e pe. (vamos para Brasilia, quando iremos e o que vamos fazer? Atrás das coisas lá) Não sei como eles chegavam lá; iam até a presidência na época era Emilio Basto de Sousa, não sei como eles iam viajar de carona, mas viajavam, mais era de pé, mas chegavam em Brasilia. E as mulheres, elas ficavam naquela preocupação, xe, oho zanemen kwe rupi zanewi wa'xi iko katete zane nehe no, pez 'e ze'eg zo pe nehe no. (nossos maridos foram por ai, vamos ficar na perfeição, silenciosamente). Tinha conselhos a'e mehe, dentro da comunidade indigena, a india mais velhas se organizava para fazer farinha, ai ficavam os outros homens na aldeia como Salomé poderia ir para Brasília, José Saprão, Marciano eles eram sub-caciques e outros ficavam como compadre Abraão e compadre Adão. A gente se organizava para ir pro mato fazer caçada, aí eu dava munição meu comportamento dentro da comunidade como indígena. Iniciava nossa vida assim, ai os homens faziam farinha tinha muita mandioca, tinha muita fartura, não tinha água só tinha cacimba no jatobá, ai o que acontecia: os outros tava viajando em busca da solução e as mulheres se reuniam zaha tar aipo ka'a pe amo semana rehe zane nehe no. (Nós iremos também para mata na outra semana) Iam as mulheres as crianças os homens carregavam a farinha e água naquele tempo não tinha água e nem cacimba no jatobá, era um ponto de caçada dos Tenetehára do Juçaral e região, como tu ainda acompanhou esse tempo... deixou tua filha com 3 meses na aldeia e foi para mata com nós e com três dias tu veio embora. Chegando lá os homens iam caçar, matava caça, veado, duas guariba, jacu. E eu como era mais liderança, parteira, tinha dado a munição ganhava mais que as outras. Se eles matava um veado, eu ganhava uma banda do veado; de duas guariba, ganhava uma inteira; jacu e era assim que nós leva a vida. Eles dividiam a caça com quem não matava, lá na mata as mulheres que cuidava da caça, antes nós indígenas era mais unidos acabou se tudo se acaba...enquanto uns iam para Brasília, outros iam para caçada, trabalhavam em união e mutirão nas derruba da roça até o plantio. Era tudo em mutirão e quando

\footnotetext{
${ }^{25}$ Maria Santana da Silva, tem 68 anos. Reside na Aldeia Ypaw My’ym, da Terra Indígena Araribóia, município de Amarantes, no estado do Maranhão, onde é cacica e atua como parteira tradicional em todo o território. Falanate bilíngue do Tenentehára e do português, estudou até o fundamental menor. Hoje, aposentada pela Fundação Nacional de Saúde (FUNASA).
} 
nos chegávamos na aldeia da caçada, nós ia repassar para as outras mulheres que tinham ficado na aldeia. Aiko uruhem kwez, amogwer rakwez uma'ezuka wà ri'i, amogwer numa'ezuka kwaw rakwez wà ri'i. (Nós chagamos agora, aqui, uns mataram caças e outros nâo mataram nada.) Então agente dividia da caça para as outras, dava caça moqueada com farinha e elas comiam lá mesmo...antes nossa vida era assim: tudo na união, nossa vida se iniciava assim.

Maria Santana fala sobre um tempo em que a saída dos homens da comunidade era decorrência, não das imposições do SPI, mas da luta do povo pelo território. Enquanto alguns homens, como lideranças de seu povo, tinham a imcumbência de negociar com o Governo: "zaha tar brasilia pe ("vamos para a Brasília"), até a presidência”, as mulheres, assim como outros homens, permaneciam nas comunidades. A divisão do trabalho parecia se estabelecer de forma menos diferenciada se levarmos em consideração que, segundo Maria Santana, "[...] os homens faziam farinha... tinha muita mandioca [...]" e que as mulheres também iam pra caçada:

[...] tu (Cintia Guajajara) ainda acompanhou esse tempo... deixou tua filha com 3 meses na aldeia e foi para mata com nós e com três dias tu veio embora. [...] lá na mata as mulheres que cuidava da caça.

Além de marcar a força da coletividade Tenetehára: "[...] enquanto uns iam para Brasília, outros iam para caçada, trabalhavam em união e mutirão nas derruba da roça até o plantio [...]”, o depoimento de Maria Santana também reafirma a posição de liderança ocupado pelas mulheres: ela própria Maria Santana é essa liderança: "[...] E eu como era mais liderança, parteira, tinha dado a munição, ganhava mais que as outras."

Reconhecida por sua liderança e como chefe de família, Maria Santana também é lembrada pela sua takihetàn ("catana"/tipo de facão) que carrega junto de si, especialmente, nos momentos de ritual. O instrumento, segundo ela, simboliza a força e a combatividade: a takihetàn que impunha é o "fação de Tuira"26, ou seja, é a sua arma enquanto "guerreira Tenetehára". Ao mesmo tempo que assume essa posição tradicionalmente masculina, Maria Santana, ao usar esse instrumento, afirma também sua posição enquanto mulher Tenetehára tradicional, aquela responsável pela roça ${ }^{27}$, já que takihetàn é usado na capina.

\footnotetext{
${ }^{26}$ Tuíra é uma indígena Kayapó que ficou conhecida pelo episódio ocorrido, em 1989, durante uma audiência pública na cidade deAltamira (PA). Nessa audiência convocada pela Eletronorte, para discutir a construção da usina Kararaô (UHE Belo Monte), localizada no Rio Xingu, Tuira admoestou o então presidente da Eletronorte, José Muniz Lopes, sobre os perigos dessa obra encostando a lâmina do seu facão no rosto do presidente.

${ }^{27}$ No mito a "Entrega da Sementes", a mulher a responsável pelo surgimento horticultura, é a protetora das sementes: "[...] o desacato (não acreditar) às palavras de Maíra leva ao
} 
As três mulheres Tenetehára da mesma geração, sobressaem-se por assumirem posições tradicionalmente masculinas: enquanto Maria Santana "antes de ser servidora pública do governo" e Verônica Tembé "junto com o marido", assumem o papel de liderança e chefe de família, à Pirawehy (Zilda Guajajara) como "ajudante" do pajé, de seu marido Tomaizinho, foi permitido fazer contato com sobrenatural, com os "encantados".

A emergência desses sentidos contraditórios, portanto, são indicadores de que as condições impostas pela memória do contato parece não ter caráter absoluto sobre a dinâmica dos gêneros na sociedade Tenetehára. E se por um lado a "a ausência dos homens", "as políticas públicas" ou os "movimentos sociais", são impulso para mudanças, por outro são também material sujeito à "falha". De fato, do conjunto de enunciados que se repetem - determinados pelas filiações de sentidos formadas por meio das relações de poder que sustentam a FDIndT - vemos emergir aqueles que remetem à valorização da cultura/ tradição Tenetehára. Dos discursos das mulheres Tenetehára apresentados, todos materializam os sentidos da tradição. $\mathrm{O}$ discurso de Suluene Kuzàwy é tomado, aqui, como exemplar:

"[...] e quanto à liderança, o espaço que estou ocupando hoje, vem da raiz".

"[...] nós temos um grande respeito pelos cantores, pelos pajés, porque eles é que tá nos ensinando, e hoje eu trago essa raiz revitalizada, essa força da tradição, nossa raiz, da nossa tradição e trago vivo e vou manter a sequência dessa força pra minha familia pra minhas filhas, pra minhas netas e pra minhas bisnetas."

Assim, na tecissitura discursiva da FDIndT, os pequenos lugares de esgarçamento surgem e se constituem pela força da tradição. É portanto o "conjunto complexo de atitudes e representações" (Pêcheux \& Fuchs, [1975] 1997:166) da cultura tradicional Tenetehára que mobilizado, passa a sustentar e legitimar a "flexibilização" das posições de gênero. Essa estratégia minimiza a força da ideologia dominate, já que a flexibilização, que permite à mulher Tenetehára assumir posições tradicionalmente masculinas, ao se produzir concomitantemente ao intenso movimento de valorização cultural silencia a memória do contato. De tal modo, semelhante à ressignificação do mito Maira 'yr e Mykura'yr feita por Cipriano Gajajara, também a posição/identidade da mulher Tenetehára é ressignificada: um novo dizer sobre essa mulher surge

surgimento da horticultura. Se a mulher não tivesse procurado descobrir (desconfiar) o que o marido estava comendo não teria conseguido as sementes para plantar. E se esta tivesse ido à roça buscar os produtos no dia seguinte, não haveria horticultura. Isto é, para que a horticultura se tornasse uma atividade importante da sedentarização parcial dos Tenetehara, era necessário que a mulher desacreditasse de Maíra." (Zannoni, 2002:89). 
ancorado pelos limites da FDIndT.

Isso posto, tornam-se relevantes as afirmações de Ponte \& Aquino (2013) sobre os Tenetehára-Tembé do Gurupi, quando apontam por um lado a emergência de importantes lideranças femininas, e por outro a manifestação do que afirmam ser uma dinâmica marcante de reafirmação da identidade e da cultura Tenetehára. Junte-se isso, a situação envolvendo o ritual de passagem feminino junto aos Tembé, que pela sua singularidade também serve como elemento para a compreensão da interação entre a tradição e as relações de gênero.

Sem se almejar a análise dos rituais em si, diremos que na sociedade Tenetehára, a Kuzà Waza Ipiynykaw ("Festa da Menina Moça”) é o ritual de passagem feminino que marca a preparação das meninas para a vida adulta ${ }^{28}$, e a Kwaharer wa pynikaw ("Festa dos Rapazes") é o ritual de passagem masculino, que simboliza a preparação do rapaz para a vida adulta. Curiosamente, junto aos Tembé do Gurupi esses cerimoniais de passagem ganham novos contornos. Se por um lado, a Kuzà Waza Ipiynykaw ("Festa da Menina Moça") divergindo do ritual "original", ressalta também a presença masculina: o homem ganha importância na festa desempenhando o papel do "guerreiro e caçador", por outro, a Kwaharer wa pynikaw ("Festa dos Rapazes") é silenciada, pois sob a liderança de Verônica Tembé29, foi amalgamada ao ritual Wyra'u haw ("Festa da Moça").

Assim, mesmo com a introdução dos "corajosos guerreiros e exímios caçadores" no ritual feminino, em que se constrói um lugar de destaque para o homem:

Diz-se isso tomando-se como referência a simulação de uma caçada durante o ritual, uma vez que as lideranças procuram demonstrar às novas gerações, também em momento de festejo, aspectos da vida dos Tembé importantes para serem aprendidos, por serem constitutivos da transformação dos rapazes em homens fortes - corajosos guerreiros e

\footnotetext{
${ }^{28}$ De acordo com Zannoni (1999 apud Ponte \& Aquino 2013:6) a Festa da Menina tinha "importância substancial para a organização social, econômica e política dos Tenetehára uma vez que possibilitava aos chefes de família tecerem relações com outras famílias, aumentando seu prestígio por meio da aliança do casamento. Por essa razão, o autor refere o ritual como de apresentação das moças a possíveis matrimônios, possibilidade dos chefes de família de ampliar seus laços de parentesco e assim o seu poder. [...] Acredita-se que esta relação da "festa da moça" com o fortalecimento dos laços de família extensa ainda se façam presentes entre os Tembé do Gurupi, ainda que o poder político do chefe, ou da liderança atual, não esteja exclusivamente ligado a essa condição".

29 "É à senhora Verônica, hoje idosa e sem muita autonomia devido a um grave problema de saúde, que os Tembé atribuem a retomada da realização da "festa da moça" e de outros rituais, nos anos de 1970." (Ponte \& Aquino (2013:6)
} 
exímios caçadores, características masculinas de grande valor. (Ponte e Aquino 2013:9)

é a memória do "feminino" que sustenta a tradição: o ritual escolhido, o que permanece, é o da iniciação feminina. Essa ressignificação do ritual ao mesmo tempo que atualiza a memória do "caçador" e do "guerreiro" com o respectivo esquecimento da memória do homem que "faz contato com os encantados" (pajé), estabelece uma posição privilegiada para as mulheres. Essa posição reforça o seu papel enquanto repositórios da cultura e da tradição garantindolhes legitimidade para assumirem posições de liderança.

Nesse ponto, engendra-se outra proposição: a flexibilização das posições gênero na FDIndT legitimadas pela tradição, institui-se amparada pelo baixo nível de conflito nas relações de força entre os gêneros na sociedade Tenetehára. Mais uma vez a voz de Suluene Kuzàwy é exemplar:

"[...] Temos jovens estudantes, acadêmicos graduados, sempre ligados na raiz sempre ligados no conhecimento tradicional e aqui eu não sou feminista, mas sou feminina de estar no cargo de estar de igual pra igual conquistando cada vez mais o respeito dos parentes. [...]"

$\mathrm{O}$ discurso de Suluene Kuzàwy opera materializando o embate já esperado entre FDIndT e a FDNInd. Sustentando falha, uma "palavra por outra" "feminina por feminista"- instaura a contradição. Contudo, mais do que uma estratégia de negociação do sujeito Tenetehára com a ideologia dominate, o discurso de Suluene Kuzàwy materializa o baixo nível de confronto nas relações gênero da FDIndT que, possivelmente, contrasta com as relações de força na outra FD (FDNInd). Essa questão vai ao encontro da posição de Butler (1990 apud Carvalho 2011:3) quando afirma que "gênero é um fenômeno inconstante e contextual, que denota 'um ponto relativo de convergência entre conjuntos específicos de relações, cultural e historicamente contingentes"'.

A flexibilização das posições gênero da FDIndT, desse modo, pode ser entendida como resultado de "conjuntos específicos de relações, cultural e historicamente contingentes" que definem como não conflituosa (ou pouco conflituosa) a natureza das relações de força entre os gêneros nesta FD. A mulher Tenetehára, assim, não se reconhece sem a devida reformulação em um discurso feminista, pois, como sujeito de sua FD é determinada por relações de força específicas constituídas por esse baixo nível de confronto entre gêneros. É por isso que, como afirma Carvalho (2013:1), a politização das mulheres indígenas e a reivindicação de direitos mais particularmente relacionados ao seu gênero, não podem ser interpretadas, automaticamente, como a tentativa de compartilhar os mesmos direitos acionados por mulheres de outros contextos culturais não indígenas. 
Contudo, nesse jogo de alianças e confrontos, Suluene Kuzàwy ao mesmo tempo que nega o discurso feminista, constrói um espaço de negociação com esse mesmo discurso:

"[...] eu me sinto empoderada de estar sendo reconhecida por estar assumindo esse espaço."

A expressão "empoderada" atualizando a memória da FDNInd remete aos sentidos do feminismo. E à semelhança das relações estabelecidas entre as famílias extensas ${ }^{30}$, Suluene Kuazàwy, liderança que é, agencia conflitos e alianças buscando ampliar sua própria rede de relações.

\section{A mulher Tenetehára contemporânea: uma conclusão possível}

A identidade/posição da mulher Tenetehára contemporânea (MTC) fundase na tensão entre as vozes da mulher Tenetehára tradicional (MTT) e da mulher Tenetehára não tradicional (MTNT). O embate entre essas duas posições é regulado pela FDIndT, que por sua vez, particulariza-se na sua relação interdiscursiva com a FDNInd.

Se por um lado, na atualidade, o protagonismo da mulher Tenetehára dentro e fora de sua comunidade pode ser relacionado à influência dos movimentos sociais, por outro afirma-se que são as relações de força no interior da FDIndT o elemento determinante. De fato, é o contexto sócio-histórico-ideológico Tenetehára, organizador das relações de gêneros (posições da mulher/homem), o que determina a constituição da identidade da mulher Tenetehára contemporânea e, por conseguinte, sua posição de protagonismo.

O dinamismo das relações de gênero na FDIndT, que se estabelece por uma "flexibilidade" entre as posições da mulher e do homem, permite à mulher assumir posições tradicionalmente masculinas. Essa flexibilização das posições gênero se institui regulada tanto pelo baixo nível de conflito nas relações de força entre os gêneros na sociedade Tenetehára, quanto pelo poder da tradição. O discurso de Maria Santana mais uma vez mencionado, é exemplar para evidenciar os vínculos entre a flexibilidade das posições de gênero e a memória da tradição: sua posição de "guerreira" constitui-se nos limites da outra posição, a de mulher Tenetehára tradicional que deu origem à horticultura, sendo sua takihetàn a materialização dessa relação.

O deslocamentos das posições de gênero, dessa perspectiva, são tolerados e até mesmo desejados, pois vão funcionar garantindo a eficácia da coletividade

\footnotetext{
30 “[...] retomando a perspectiva dos conflitos que ocorrem frequentemente entre as famílias extensas e suas redes de apoio, entendo que os mesmos não devem ser interpretados como causa, tampouco efeito, mas como instrumentos utilizados consciente ou inconscientemente pelos tentehar na tentativa de ampliar suas próprias redes." (Almeida 2012:141)
} 
Tenetehára. A análise aponta, assim, para minimização do valor dos movimentos sociais no "empoderamento" dessa mulher. O discurso contemporâneo de valorização da identidade indígena/da mulher indígena, que tem nos movimentos sociais seu destaque máximo, funcionaria, então, potencializando o protagonismo que a mulher Tenetehára já tem dentro de sua própria sociedade.

\section{Referências}

Aguilar. Alejandra de. 2013. A identidade étnica feminina no movimento indígena: um novo ator emergente da sociedade civil na Era da Informação. In Revista Al Sur de Todo. Revista Multidisciplinaria de Género, No 4. http:// www.alsurdetodo.com/?p=191. Acesso em 29/06/2019.

Almeida, Emerson Rubens Mesquita. 2012. "SER COMO O BRANCO, NÃO É SER O BRANCO": dinâmicas de controle e transgressão nas relações interétnicas. Dissertação de Mestarado. PPG em Sociologia e AntropologiaUniversidade Federal do Maranhão.

Butler, Judith. 2003. Problemas de gênero:feminismo e subversão da identidade. Rio de Janeiro: Civilização Brasileira.

Carvalho, Maria Rosário de. 2016. A questão do gênero em contextos indígenas. In Revista Coletiva. No. http://www.coletiva.org/index.php/artigo/a-questaodo-genero-em-contextos-indigenas Acesso em 18/11/2016.

Galvão, E. 1978. Encontro de sociedades. Rio de Janeiro, Paz e Terra. Haroche, C. Pêcheux, M. Henry, P. 2008. A Semântica e o Corte Saussuriano: Língua, Linguagem, Discurso. [1971] Revista Linguasagem, São Carlos, SP, n. 3, out./nov.

Meireles, M. M. de. 2012. Sujeito(s), Representações, Discursos e Identidade(s) Polifônica(s): Entrelaçando Conceitos. In III Simpósio Nacional Discurso, Identidade e Sociedade (III SIDIS): Dilemas e Desafios na Contemporaneidade. IEL/UNICAMP- Campinas. Acesso em 30/06/2019 http://www.iel.unicamp. br/sidis/anais/pdf/MEIRELES_MAXIMIANO_MARTINS_DE.pdf

Orlandi, Eni P. 1999. Análise de discurso: princípios e procedimentos. Campinas, SP. Pontes.

Orlandi, Eni P. 1988. Discurso e leitura. São Paulo: Cortez; Campinas: Ed. UNICAMP.

Orlandi, Eni P. 1987. A linguagem e seu funcionamento. 2.ed. São Paulo: Pontes, Pêcheux, Michel. 1988. Semântica e discurso: uma crítica à afirmação do óbvio. Campinas, Editora da UNICAMP. [1975]

Orlandi, Eni P. 1997. O discurso: estrutura ou acontecimento. Campinas, SP: Pontes. [1983]

Ponte, Vanderlúcia da S. \& Aquino, Maria José da S. 2013. "Para ser mulher verdadeira!" Os Tenetehára-Tembé: relações entre ritual, direitos e 
estratégias de afirmação cultural em ações locais. In Revista Novo Mundo Novos Mundos. http://journals.openedition.org/nuevomundo/66051 Acesso em 30/02/2019.

Rodrigues, Aryon. D. 1986. Linguas brasileiras: para o conhecimento das linguas indigenas. Rio de Janeiro, Ed. Loyola.

Silva, Cintia Maria S. da. 2014. Awaxi Wàhuhaw (A Festa do Milho).Monografia apresentada no Curso de Licenciada em Educação Intercultural - UFG.

Silva, Cintia Maria S. da. 2018. Linguagem e identidade: a mulher Tenetehára contemporânea e sua relação com os movimentos sociais. Dissertação de Mestrado apresentada ao Mestrado Profissional em Linguística e Línguas Indígenas. Museu Nacional. Universidade Federal do Rio de Janeiro.

Veras, Marcos Flávio P. \& De Brito, Vanderli G. 2012. IDENTIDADE ÉTNICA: A dimensão política de um processo de reconhecimento. In Revista de Antropologia - Ano 4 - Volume 5.

Zannoni, C. 1999. Conflito e Coesão: o dinamismo Tenetehára; CIMI:Brasília. Zannoni, C. 2002. A Mulher e as Plantas. In Tellus, Ano 2 N.2 Abril.http://www. tellus.ucdb.br/index.php/tellus/article/view/12. Acesso em 03/07/2019.

Wagley, Charles \& Galvão, Eduardo. 1955. Os Índios Tenetehára - Uma cultura em transição. Rio de Janeiro, Ministério da Educação e Cultura.

\section{ANEXO}

\section{Maira'yr rehe ma'emume'u haw Mykura'yr rehe wà}

Cintia Guajajara

Amume'u putar akwez heremigwaw maira'yr, mykura'yr rehe wà. I'i tamuz mume'u haw, kwehe mehe nahetakwaw tyràm teneteharer wanupe rihe kamamu zo heta a'e ar mehe erezehu ipy wanupe. Amo tenenetehara tua'u zekaipo ima'eahy iko, kyhaw pupe win mehe weryr mair tyrám karuwap wi izupe tuweharupi xo a'e Tenetehára tyrám u'u wanuwi a'e. Amo ar mehe upukukatu ta'yr kury, wexak tyrám kurekurer u ikyhaw iapywype uzywá uyw pupe u'u a'e no hetekatu i'u mehe izupe a'e no, umume'u uhy pe, ihy, ihy nueruzar kwaw a'e ur wi mair a'e pe no werur mane'yw wer wanupe kury, ezutym reraha ko pe i'i izupe, utym kuzá mane'yw wer heraha kury, ku'e ire aipo hapo hu in a'e kury i'i kuzá, ezo'ok eho kury i'i zepe kuzá pe nuerur kwaw zekaipo a'e. A'e aze uhem xi a'e ko pe kury, kuhewe mane'ok hapo ipuga izuwi, na'erakwez newe i'i mair izupe, uzeputupykahy mair kury uzewyr oho wekohaw pe wanuwi, wezar nae'yw wer wamupe, ereáro putar àmàn kryr tatete nehe kury karahy mehe zo hapo tar aipo newe hehe kury i'i oho taranune izupe a'e kuzà upyta wekohaw pe, na'e zekaipo ipuru'a a'e kuzá na'a reahy imemyr ryryhu hie pe, na'e zekaipo amo ar mehe kury, ima'e nukwaw zekaipo ta'yr hehe kury, uhy rie pe hin mehe ukwaw u reimaw 
pupyr no pykahu xin tu reimaw romo na'e uzeraha kar ihy pe u reimaw pypor rupi na'e zekaipo oho waiko wà u ipypor hupi wà pe rupi wano mehe wekax maira'yr ma'eputyr iko kury, wenoenoz oho iko uhy rie pe hin mehe, opo'o ihy izupe a'e, nezewe oho iko uhy rie po ma'eputyr henoenoz py amo henozupur wi mehe no upiupi kar uhy kaw pekhy, kaw rahy kwer pe i'i ihy izupe, na katu pe nerein mehe kwaw erema'e noinoz ihewe ma i'i ihy izupe.

A'e re kury nuze'eg kwaw maira'yr uhy rye pe kury, na'e oho e iko wà kury, nuze'e kaw uhy rie pe kury, ikaruk wata re wà, uhem oho karuketea'i mehe amo tekow pe wà, uhem oho mákur izeàpyzapo mehe izupe, oh! zanekaruk aipo ma i'i maira'yr ihy a'e mykur pe, hurywete mykur hexak mehe a'e no, zanekaruk aipo pa i'i izupe a'e no ma'e pe kuzá oho, i'i hehe upuranu pá kwa hememyr itu haikwer romo aha iko ma, i'i kuzà mykur pe, pytyn kury eker ko rupi kuteri rihi pa i'i mykur kuzà pe, na'e uxuxi ikyhaw izupe kury. Ta'e àmàn imugyr kar har ihe no pa i'i mua'u izupe, ikyhaw izápixi mehewe, ukutukutuk wàpyz rehe izuwi, pakoràn huwer zekaipo hápyz rehe a'e numugwer kar kwaw mykur, kuzà a'e pytum rupi, umynyrynyhyk ikyhaw izápixi pa uxeake a'e. Umygyno'o kar kuzà a'e pe imugwer kar ym, aze uker xi kuzànezewe oho wi màkur wapuz iar romo no. Xe hekyhaw rehe zo àmàn nukyr kwaw a'e pa! I'i mua'u izupe, e'eaw ezur hepuhe pa i'i mykur kuzá pe, naiaw wer kwaw zepe kuzà, ipuhe a'e. Naizemykym wer kwaw kuzà a'e, nezewe i'a wà ipuhe, kuzà iker mehe, uzemuapixik mykur hehe kury, a'e ar mehewe uzemumurua kar wi kuzà mykur pe no, a'e ar mehe, uze'eg wi mairayr uhy rye pe no, i'i myurayr pe, nea'e eho in ne nehe no ty i'i wywyr rám pe, ku'em ire oho wi kuzà a'e wi no weraha mokoz umemyr wie pe wàkury, mair haiker romo, uhem wi oho amo ma'e puru'u ma'e wanekohaw pe no mokoz imemyr hie pe wà kury. Na'e uhem ho amo zaryz pe no, zanekaruk aipo kyn i'i mairay wa hy ho a'e zaryz pe, a'e zaryz, uzemukuhem hehe a'e, karuk aipo kyn i'i izupe a'e no, oh ma'e kwaw im zewe ezur aipo korupi kyn i'i zaryz izupe, na kohetekawaw, uhem wapaje oho a'e pe kuhewe a'e zaryr uzumym kuzá puru'a ma'e heraha zapepohu iwy pe, uzepygwaretum zekaipo wapaze a'e pe kury, zawarymy i'i wazyr pe umuzar petum ihewe pa i'i wazyr, upetumu a'e pe kury, wwexaw kuzá ipuruahu ma'e kury, petum wezar izupe ta'e ipaze katu a'e zawar uzuka kuzá ipurua ma'e kury, na'e imemyrer uzeapo ma'ea yr romo a'e.

Wà kury. Wezak zaryr a'e, i'i wamupe oh, kwaxi a'yr tuwe wà ra'a, weraha xi ixoxok wà opo oxo ygu'a rehe wà, a'e mehe maira yr ipuner wera'u a'e xote wanuwi no, weraha xi zepehe kwar rupi wà no, opo xot umir tatarakukwer pupe wà, a'e mehe maira'yr umumair wywyr kury, uzeapo wyzà'i ma'e a'yr romo wà kury te, ikweraz manuwi wá, tuwe wiko reimaw romo i'i wazaryz wanupe kury, tekte uzeapo Tenetehára romo wà kury. oh! tuwe wanekom hereimaw romo wà kury i'i zaryz wanupe.

A'e pe wiko mairayr wywyr rehe wà kury te, itua'u a'e pe wapyr wà, wazyr wazekaiw haw romo, tuwerarupi oho ko pe uzahyz agaw hupi wá, amo ar mehe ko pe wano mehe, uze'eg zaku wanupe kury, pehy i'u nuromoarer wapyr 
peiko kunumiwá, i’i wanupe, uzepyaka mairayr wà kuru, upuranu zakurehe wà, umamume'u i'i wanupe no, a'e ar mehe uza'io mara'u wà kury, heezuezun oho wà, ukwaw wazaryagaw waza'ioawer wanehe a'e, upuranu wahe kury, wárázawe peiko ra'a i'i wanupe ta'e i'i zepe tuweharupi, peho zo kwerupi muite wera'u nehe i'i zepe wanupe, ta'e ukwaw wemiapakwer, aze wexar waneha hezum menhe, upuranu wanehe kury, oh kaw e urepi kwez zaryz i'i izupe wà. Oh! nahetakaw agwer korupi a'e ma, uka kaw mono hehe wá, upiupikar uzar kaw pe wà. Tuweharupi oho ko pe uzaryw hupi, wezar zezupaw pe wà oho ka'a rupi izuwi wà kury uzáká'ok uzaryr wà oho ka'a rupi izuwi wà kury, ikaruk oho ka'a rupi izuwi wà, wizà ma'e uzapo oho iko wà kury, ta'e uhy i'u awer rehe uzepyk tar wà kury ,uparupikatu ma'e uzapo iko wà kury, maywa, miar, yrykar amo ar mehe, uzapo tapir wà kury, uzuwàn hepuxi pakopràn ruwer pupe wà wera uzaryz pe hexakar wà kury upaw Ràgàpy ma' e wyzà'i uzapo wà rihi. Nezewe oho taw pe har wapiaramo wà kury. Zaha tapi'ir piaramo i'i wanupe wà weraha paw a'e wanekwo tapi'ir ipiaromo wà kury. Oho paw wanupi a'e wà no. Wazewyr mehe wetik paw wamono y pe w'au kar ma'e y pehar wanupe wà, murake, piràz, zakare, moz, upawrupi ma'e wanupe.

Upaw wa'u kar ma'e'y pehar wanupe, uzepk uhy i'uarer rehe wanehe kury. Oho zekaipo iko u hai kwer ramo wà kuery. Ituau re oho maiko wà xirogatu ma'e iapo pa wà. Wexak àzàg ipirapoz mehe. Wazyr pume wà, uzeapo, mainumy ramo wà, upihan àzag tua'u hapi'a rehe wà. Uzeapo wi ipira ramo wà no. U'u paw piraputaw àzàg tua'u wi. Maira'yr iatkatu wywyr wi a'e uzepyhykar tywyr àzàg tua'u pe. Uzepyhykar kar tywyr àzàg tua'u pe a'e, oho Maira'yr wywyr kagwekagwer ipiaromo uzeapo tàpiàzuhu romo umono'og paw ikagwekagwer, umugweraw wi kar wywyre no. Oho wi waiko ka"a rupi wà no. Uhem oho u pe wà kury. Nukwaw kwa wanu a'e wà kury. Aexak amo àzàg iaw ipuku ma'e no kunumi wà. Ma'e pe xi'a. Ii u pe marawyp. I'i wanupe. Urexak ure nehe no, uwexak a'e wà no umunipuk tata oho iaw rehe wà. Uzàn àzàg y hekar, umypaw y izuwi wà no. Upe ihem mehe wà omomor uyw ita wà, naikàg kwaw wanu wanupe a'e kury. Ikàg wera'u ma'e romo uwi a'e wà. Ta'e uzapo wirapar moz romo wà no. Upaw rupi ma'e wyzà'i uzapo tenteharer.

\section{A história do filho de Maira e do filho de Mucura}

Vou contar aquilo que eu sei sobre o filho de Maira e o filho de Mucura. Diz a história dos tamuz (mais velhos) que, antigamente, ainda não havia farinha para os Tenetehára. Só tinha camamu (fruta silvestre com qual os Tenetehára se alimentam) para os nossos antepassados. Um índio mais velho estava doente. Enquanto ele estava dentro da rede, Maira trazia farinha do karup (lugar encantado) todos dias para ele. E somente esse índio que estava doente era quem comia a farinha, os outros não comiam. Um dia o filho dele descobriu que o pai comia farinha. Ele viu farelo de farinha de baixo da rede do pai. Ele, o filho, começou a flechar a farinha, comeu e viu que era bom. Ele contou para a mãe da descoberta da farinha. A mãe 
dele não acreditou.

Na próxima visita de Maira, ele já trouxe a maniva (broto da mandioca). Maira entregou para a mãe do menino para ela plantar na roça. Ela foi plantar a maniva. No outro dia, Maira falou para a mulher: a mandioca já está pronta para fazer a farinha, vai lá arrancar. A mulher duvidou que a mandioca já estivesse pronta. E quando ela chegou na roça, a raiz já tinha apodrecido por ela não ter acreditado. Então, Maira diz para ela: "bem que eu te disse que a mandioca já estava pronta". Maira desgostou-se com isso e voltou para o seu lugar encantado, mas deixou a raiz da maniva. Maira disse para a mulher: "agora, você vai esperar chover muito para ela criar raiz, só no verão é que você vai colher a mandioca". A mulher ficou na sua aldeia e logo engravidou misteriosamente e o seu filho também cresceu rápido na barriga dela e já se lembrou do seu pai. Ele era Maira'yr (o filho de Maira). Enquanto ele estava na barriga da mãe já sabia do rastro do animal de estimação do seu pai. O nome do animal de seu pai era inamuxig (nambu branco). Então, ele fez sua mãe carregá-lo pelo rastro do animal de estimação de seu pai. Então, foram andando pelo rastro do animal. Enquanto eles foram caminhando, Maira'yr (filho de Maira) começou a ver flores pelo caminho. Mesmo dentro da barriga da mãe começou a pedir para ela colher flores. Sua mãe começou a colher flores para ele. E era assim que ele ia seguindo, pedindo flores para a sua mãe. Chegou o momento que ele pediu novamente e fez a mãe ser ferrada por marimbondos. Naquela hora, ela sentiu muitas dores e falou para o filho: "você não está nem fora do meu ventre para estar pedindo essas coisas".

Depois que ela foi ferrada por marimbondos e falou sério com o filho dela, o filho não falou mais. E então foram sem direção porque ele não falava mais. Ela passou o dia caminhando até anoitecer e chegou em uma morada. Chegou nesse lugar e encontrou Mucura fazendo a casa dele. A mãe de Maira'yr (filho de Maira) disse boa tarde para Mucura. Mucura responde feliz: "boa tarde!" E perguntou para onde a mulher estava indo. "Estou indo atrás do pai de meu filho", disse a mulher para o Mucura. "Já é noite dorme por aqui hoje", disse Mucura para a mulher. Então, atou a rede dela e disse que também fazia chover, mas mentiu para ela enquanto atava a rede. Ele subiu na casa e ficou furando o telhado que era feito de folha de bananeira brava. Durante a noite Mucura não deixou a mulher dormir por conta da goteira na casa. Ele ficou mexendo na rede dela até chegar pertinho dele. Então, ele cansou a mulher sem deixar ela dormir, quando a mulher queria dormir ele ia lá em cima fazer outro buraco na casa. Mucura disse mentindo para ela: "Só aqui na minha rede é que não está molhando, venha dormir comigo". A mulher não queria deitar com ele, mas como ela não queria se molhar deitou. Foi por essa razão que deitou com ele. Enquanto a mulher dormia ele se aproveitou dela e na mesma hora ela engravidou de Mucura. Foi nesse momento, que o filho de Maira voltou a falar novamente. Ele disse para aquele que iria ser seu irmão, para Mykura'yr (filho de Mucura), que fosse procurar outro canto. No outro dia, a mulher sai da casa do Mucura e já leva os dois gêmeos na barriga. Sai em busca de Maira. Então chega na morada zawar puru'u ma'e (cachorros comedores de 
gente). Lá a mãe dos gêmeos encontra uma velhinha e a cumprimenta dando boa tarde. A velhinha leva um susto, mas responde dando boa tarde e dizendo: "Oh! Você só veio por aqui porque não sabe de nada". De repente, chega o homem que era filho da velhinha, mas ela já tinha escondido a mulher de baixo de uma panela grande. O filho, que era um zawar puru'u ma'e (cachorros comedores de gente) ficou farejando a mulher sem encontrá-la e chamou sua filha Zawarimy para trazer um cigarro. Quando fumou descobriu a mulher de baixo da panela. Esse zawar era um grande pajé e por isso descobriu e, imediatamente, matou a mulher. Quando mulher morreu e tiraram os filhos dela, eles, os filhos, já se transformaram em animais. E então a velhinha viu que eles se transformaram em quatis: "Ah! São filhotes de quatis disse a velhinha". Levaram os filhos de Maira, que eram quatis para socar no pilão, mas pelo poder deles, eles não morreram. Jogaram eles na fornalha e eles não se queimavam, somente os que os jogaram queimaram as mãos pela quentura do fogo. "Oh! Deixem eles ficararem como meus animais de estimação", disse a velhinha. Nesse momento, é que o filho de Maira deu poder para o irmão que era filho de Mucura. Eles dois foram se transformando em outros seres até chegar a forma de Tenetehára. E lá eles ficaram sob os cuidados da velhinha até ficarem rapazes crescidos. Eles iam para a roça todos os dias com a suposta vó. Um dia, eles iam pelo mato e encontram um Jacu e este disse que eles estavam morando com o povo que tinha comido a mãe deles. Então, eles choraram muito até ficar com o rosto inchado. Voltaram para junto da velha e ela perguntou: "O que aconteceu com vocês meus filhos?" Eles disseram que foram os marimbondos. A vó disse para eles: "Aqui não tem dessas coisas". Foi então que eles soltaram os marimbondos, que já tinham criado lá no mato e eles esporaram a velhinha. Depois disso, quandos os gêmeos foram novamente para o mato, já estavam preparando uma vingança para esse povo que comeu sua mãe. Lá eles criavam coisas, tudo da natureza: os frutos, as caças os peixes, os outros bichos da água: como jacaré, puraqué, piranha e cobras e com isso se preparavam para se vigar. Um dia, criaram uma anta e trouxeram as fezes para provar que existia, pois o povo não a conhecia. Eles convidaram todos para ir buscar essa anta que disseram que tinham caçado. Não podiam trazer sozinhos, pois ela era muito grande e, por isso, precisavam de ajuda do povo todo. E quando todos estavam voltando com a anta, os gêmeos fizeram com que todo o povo que tinha ido junto e que tinha comido sua mãe, fossem, eles próprios, comidos pelos bichos da água. Depois de fazer a vigança de sua mãe, os gêmeos seguiram a procura de seu pai, Maira. Quando encontram, Maira disse para eles: "Eu sei aonde tem um àzàg (espírito mau da floresta) de cabelo bem comprido". Os gêmeos perguntam: “Aonde?" E o pai responde: "Marawyp (não sei)". Os gêmeos aceitam o desafio e vão a procura do àzàg e quando o encontram queimam o cabelo dele. Àzàg, então, sai correndo a procura de água e quando ele chega na lagoa, os gêmeos já tinham secado a água. Voltam para junto do pai deles e continuam com outro desafio que era de transformar arco em cobra. E eles ficaram com mais poder do que o seu pai. 